\title{
The Choice of the Technical Liquidation of Underground Mine Workings
}

\author{
J. Dvořáček VŠB-Technical University of Ostrava, Czech Republic
}

J. Štěrba V̌̌B-Technical University of Ostrava, Czech Republic

\section{INTRODUCTION}

The mining legislation in the Czech Lands is more than seven centuries old and the development of mining has been marked by ups and downs during the whole period. The 1990s were characterised by the closing down and liquidation of underground mines, which, under new conditions, failed to cope with the economic and environmental criteria introduced. The fast initial liquidation of underground mines led to surface faults and destruction of mine workings, collapses of shaft tops, escape of methane to the surface and resultant explosions, and contamination of mine water discharging from or pumped out of flooded mine workings, as a result of improper liquidation of the mines. The fact of the matter has prompted the state mining authority to seek the method of technical liquidation of underground mines, which would be a final solution to the issue without any impact on the society or the environment.

\section{BASIC METHODS OF TECHNICAL LIQUIDATION OF UNDERGROUND MINES}

In the Czech Republic the basic methods of technical liquidation of underground mines are (Dvořáček and Slivka, 2005):

- Flooding.

- Backfill by loose material.

- Hydraulic stowing.

Combinations of the above have also been used - backfill in aqueous medium or hydraulic stowing and backfill by loose material in one shaft. The combination method is the condition when the proportion of both the components is approximately equal. A single flooding or backfill by loose material is not used - the shaft is always closed by concrete or other solid material.

\subsection{The Liquidation of Underground Mines by Means of Flooding}

A long time ago flooding of mines used to be a frequently used method of technical liquidation. The main mine workings leading to the surface were locked up and the mine was left to the influence of natural elements. A later approach was connected with the construction of dams separating horizontal workings from the shaft or isolating individual allotments underground. The prerequisite is the removal of all machinery and materials which could cause mine water contamination.

The advantages of this method of technical liquidation:

- Very low costs of technical liquidation.

- In the case of the wet mine conservation there is a theoretical possibility to resume mining in the future after the water has been pumped out of the flooded underground spaces.

The disadvantages connected with this method of technical liquidation:

- In the case of discharge of mine water or its pumping out it is necessary to build a mine water purification plant for long-term or even continuous decontamination of mine water. 
- Necessity of long-term monitoring of the flooding process, the condition of the flooded mine workings and the decontamination process.

- In the case of flooding of a number of mines it is necessary to build the water pits so as to eliminate flooding of productive mines.

A flooded underground mine cannot be considered irreversibly closed as it enables two different subsequent strategies - after the water has been pumped out, mining can be resumed or another method of technical liquidation can be used, such as backfill in aqueous medium.

\subsection{The liquidation of Underground Mines by Means of Backfill by Loose Material}

The method was frequently used in the 1990s. In principle it was the backfill of underground mines whereas horizontal workings were separated by dams or they were stuffed with loose material with respect to its weight and loosening in water. The subsidence of the backfill required checking of its condition and additional filling through the cover of the shaft on the surface. Loose material used for backfill was rubbishtip material, industrial waste from coal preparation, material from demolitions of buildings, and broken rock. In case that grain size in the backfilling material was not kept (greater than $250 \mathrm{~mm}$ ) or obstructions were left in the shaft (piping etc.), cavities would occur in the backfill, which would subsequently collapse.

The advantages of this method of technical liquidation:

- Short time required for the backfill itself.

- Possibility to use low-cost and available sources of backfilling material.

- Relatively low costs of technical liquidation.

The disadvantages connected with this method of technical liquidation:

- Risks connected with imperfect backfill of the liquidated mine workings.

- Danger of loosening of the backfill as a result of exceeding the bearing capacity of the sealing dams on individual levels of the underground mine.

- Long-time monitoring of the backfill condition in the liquidated shaft and the necessity of additional filling by backfilling material.

- Liquidation of the main mine workings while underground spaces are left free.

- Unawareness of the behaviour of the loose backfill after its flooding by water in a long-time perspective.

The technical liquidation of an underground mine by loose backfill is incomplete as it primarily concerns the shaft. The remaining underground spaces are flooded and enable both mine water contamination and impairing of the stability of the rock mass.

\subsection{Liquidation of Underground Mines by Means of Hydraulic Stowing}

In the past mixtures of ashes and flotation waste rocks were used in underground coal mining for stowing of the stoped-out workings. Both research and practice have shown that other industrial wastes can be used for the production of the hydraulic stowing as well. The materials used were e.g. wastes from slag processing, dust from coal combustion, wastes from the non-ore mining industry, wastes from the cement industry, wastes from stone processing, and sand.

The liquidation of mines by hydraulic stowing enables filling of the main mine workings as well as all the underground spaces. The stowing mixture, which is produced from industrial wastes by a surface technological line, is transported underground in liquid condition through a pipeline. At its destination the mixture solidifies into the strength conforming to its composition and substitutes the original rock. The process is conducted from the lowest levels to the surface and from the limits of the allotments to the shaft. 
The liquidation of mines in successive steps enables continuous monitoring of the quality of water, mine workings are ventilated and monitored.

The advantages of this method of technical liquidation:

- Preventing mine water contamination as well as the need for pumping out and purification.

- Preventing methane from escaping to the surface.

- Preventing the liquidated mine workings from affecting the surface.

- Final solution to problems with enormous volumes of industrial waste which would otherwise be disposed of on surface dumps and stockyards.

The disadvantages connected with this method of technical liquidation:

- Rather a long time taken for the execution of the liquidation work due to technological downtimes required for solidification of the mixture.

- Necessity of separate airing of shafts during their liquidation.

- Rather high costs for production of stowing mixtures and their transport to the destination.

The most significant contribution of the method of technical liquidation is the return of the rock mass to a condition which is similar to the condition prior to the mining activities. The method solves the problems with methane, mine water, and stability of the surface.

The basis for the production of consolidated stowing mixtures is industrial wastes, which, however, does not mean underground depositing of waste. The produced stowing mixture is classified as a secondary raw material or product since the process of solidification is accompanied by alteration of physical and chemical properties of the input components, i.e. wastes. The stowing mixture has to conform in terms of:

- Physico-mechanical properties (compression strength, porosity, permeability).

- Chemical properties (leachability).

The stowing mixtures must not have negative impact on the environment - by leaching they must not release harmful substances into mine and ground water in an amount, which, by a long-term action, might inadmissibly affect ground or surface water. The transport of harmful substances from the stowing mixture can be controlled by two methods:

- Chemical or physical treatment of wastes, which will reduce the mobility of harmful substances and their release from the consolidated material.

- Technical securing of the stowing mixture, which creates a barrier to the transport.

Technical barriers in the form of dams in horizontal workings and plugs in pits perform their function in various ways as they are able to:

- Prevent mine water from entering the stowing mixture.

- Prevent further transport after the discharge from the stowing mixture.

- Block the routes of contamination.

The contact of stowing mixtures with ground water has to be considered from a long-term perspective. The usability of stowing mixtures is found from the quantitative evaluation of the possible discharge of harmful substances into ground water and the anticipated impact on the environment.

\section{CONCLUSION}

The technical liquidation of underground mines is in fact a unique process as it stems from specific natural conditions, the method of filling of underground spaces, the materials and technology used, and organization of work. Based on the analysis of a few tens of the cases of technical liquidation conducted since the early 
1990s in the Czech Republic it can be said that the methods of technical liquidation of underground mines differ in terms of:

- Extent of elimination of the safety and ecological risks connected with the liquidated underground mines.

- Rate of execution of the technical liquidation.

- Financial requirements for the work done.

Mining activities are connected with the temporary depriving of the area of its original use. The liquidation of an underground mine should restore the condition of the area to be as close to the original condition as possible. With regard to the above facts the following conclusions to the individual methods of the liquidation of underground mines can be made:

- Flooding of mines is not a final solution to the issue of liquidation and it should not be used very often.

- Backfill by loose material is suitable for deposits with incomplete development, because with deposits of long-term exploitation the final restoration of the original condition of the area cannot be so ensured.

- The liquidation of underground mines by hydraulic stowing of both vertical and horizontal mine workings is a universal method of technical liquidation. In this way the original condition of the area influenced by mining activities is restored and safety and ecological risks connected with closed underground mines are eliminated.

The experience in the Czech Republic shows that the rather high costs of the liquidation of underground mines by hydraulic stowing can be handled by means of:

- Use of industrial wastes with higher disposal costs and the removal of which is paid for by the producers of the wastes.

- Cutting of the fixed costs of the mine under liquidation depending on the decreasing number of levels, lower amount of pumped out water, lower extent of ventilation, etc.

- Increasing of the stowing capacity, which will increase the income for removal of industrial wastes from their producers for the purpose of further treatment.

- Reducing of the dismissal of the mine staff who will do the liquidation work and thus reducing the social costs connected with the closing down of the mine.

Hydraulic stowing produced from industrial wastes is a final solution to the use of high volumes of waste, which has predominantly been disposed of on surface dumps with all the negative impacts on the environment.

\section{ACKNOWLEDGEMENTS}

The contribution was made thanks to the Project of the Czech Mining Authority No. 42-05.

\section{REFERENCES}

Dvořáček, J. and Slivka, V. (2005) Technicko-ekonomická analýza způsobu technické likvidace hlubinného dolu zakládáním. Final report to the project Science and Research of the Czech Mining Authority No. 42-05, Ostrava, 2005, 87 p.

Slivka, V., Grmela, A., Hudeèek, V., Rùrek, P., Petro, V. and Danì, T. (2006) Analýza technologie likvidace dolu zakládáním vycházející z technického projektu likvidace dolu. Partial report to the project Science and Research of the Czech Mining Authority No. 42-05, Ostrava, March 2006, 168 p. 